An ESRC Research Group

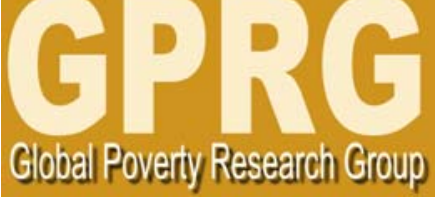

\title{
Empirical determinants of corruption: A sensitivity analysis
}

\author{
GPRG-WPS-012
}

Danila Serra

Global Poverty Research Group

Website: http://www.gprg.org/

The support of the Economic and Social Research Council (ESRC) is gratefully acknowledged. The work was part of the programme of the ESRC Global Poverty Research Group. 


\title{
Empirical determinants of corruption:
}

\section{A sensitivity analysis*}

\author{
Danila Serra $^{\dagger}$
}

Revised: June 2004

\begin{abstract}
Many variables have been proposed by past studies as significant determinants of corruption. This paper asks if their estimated impact on corruption is robust to alteration of the information set. A "Global Sensitivity Analysis", based on the Leamer's Extreme-Bounds Analysis gives a clear answer: five variables are robustly related to corruption. Corruption is lower in richer countries, where democratic institutions have been preserved for a long continuous period, and the population is mainly Protestant. Corruption is instead higher where political instability is a major problem. Finally, a country's colonial heritage appears to be a significant determinant of present corruption.
\end{abstract}

JEL Classification: D72, D73, H11

Key words: corruption, determinants, sensitivity, robustness, extreme-bounds.

*I am grateful to Oriana Bandiera, Eliana La Ferrara, Guido Tabellini and an anonymous referee for their useful comments and suggestions. I am also indebted to Francesco Daveri and Andrea Galeotti for precious discussions on the main idea of the paper.

${ }^{\dagger}$ CSAE, Department of Economics, University of Oxford. danila.serra@economics.ox.ac.uk 


\section{Introduction}

In recent years the presence of corruption all over the world has attracted the attention of economists and public opinion. The awareness of the dramatic effects of corruption on a country's development leads to investigate why corruption exists and what makes it so differently widespread among countries. A number of studies have recently pointed out the correlation between a large set of variables and corruption. However, controversial results seem to be quite common when adopting different measures of corruption, different samples, or, more important, different conditioning sets. In such a context, unless a thorough sensitivity analysis were carried out to control the robustness of variables apparently significant, we would never stop wondering whether we might find the same results by trying another specification; this is exactly what this paper wants to highlight.

My aim is to find any truly robust determinants of corruption among the various factors identified by past empirical studies as significantly related to corruption. I conduct on previous findings a systematic "Global Sensitivity Analysis" based on the Edward E. Leamer (1978, 1983, 1985) Extreme-Bounds Analysis (EBA) as modified by Levine and Renelt (1992). According to the EBA, an explanatory variable is "robust" only if its estimated coefficient remains statistically significant and maintains the same sign in all the regressions run with different sets of control factors.

A total of 16 variables are tested for robustness: 4 economic variables (economic development, openness to international trade, state intervention in the economy, endowment of natural resources), 5 sociocultural variables (British legal system, British colonial Heritage, Protestant religion, ethnolinguistic fragmentation, education of the population) and 7 political variables (base political rights, uninterrupted democracy, freedom of information, mass media diffusion, federalism, electoral system, political instability). In practice the EBA is conducted on 28 proxies since I employ different measures for some variables and I also conduct the EBA on new 
variables generated by employing the principal component analysis on highly correlated explanatory variables. Unfortunately many explanatory variables which have been included by past studies among the potential determinants of corruption are clearly endogenous. One should be aware that for these factors the EBA could only identify robust correlations, whereas the causal direction remains an open issue which is possibly left to future research.

This paper also makes a contribution to the EBA methodology: for the first time, to the best of my knowledge, the robustness check is conducted on vectors of dummies instead of a single variable of interest. I indeed test the robustness of 2 vectors of dummies: a legal vector, composed by all the legal origin dummies introduced by La Porta et al. (1998), and a colonial vector accounting for each country's colonial heritage.

The data employed cover a total of 62 countries, both developed and developing; the measure of corruption used is the Graft index by Kaufmann et al.(1998). I also check my findings by replacing Graft with the average value of Corruption Perception Index (CPI by Transparency International) for the period 1997-1999.

The EBA results strongly support the work by Treisman (2000) and can be summarized as follows. Five variables passed the Extreme Bounds Analysis. These are: economic development, Protestant religion, colonial heritage, uninterrupted democracy and political instability. First, the estimates show a negative strong correlation between economic development and corruption: as theoretically predicted and empirically shown by previous studies, corruption is lower in richer countries. Second, the dummy for uninterrupted democracy shows a strong statistically significant coefficient with the predicted negative sign in all the regression run. As Treisman (2000) pointed out, what seems to reduce corruption is not the actual level of democracy, but whether a country has maintained democratic institutions for a long continuous time. Third, the regressions run for political instability suggests that a higher level of political instability is associated with a higher level of overall corruption. Fourth, countries where citizens are prevalently Protestant seem to be less corruption, as previously documented by La Porta et al. (1999) and Treisman (2000). 
Finally the robustness of the colonial vector provides evidence that a country's colonial history did play a role in determining its actual level of corruption. This result strongly supports the arguments and findings of Tresiman (2000) that it might be a country's "legal culture" rather than the presence of a common low legal system that directly influences corruption.

This paper makes a contribution to the empirical literature that seeks to understand the causes of corruption. In particular the sensitivity analysis implemented shows that most variables presented as robust in previous studies are instead highly sensitive to changes in the empirical specification. A number of measures are taken in order to prevent the EBA results to be driven by multicollinearity among the explanatory variables. When this is the case the correlations that could bias the EBA findings are highlighted. Moreover, the unlikelihood to pass this highly demanding test should be seen as an additional reason to believe that those variables which succeded are undoubtely related with corruption.

The paper is organized as follows. Section 2 briefly presents the primary findings and controversies of the empirical literature on corruption's determinants. Section 3 and Section 4 describe the specific estimate process and the data used. Section 5 discusses the empirical results and Section 6 summarizes the main findings.

\section{Controversies in the Empirical Literature}

When looking at the most recent and relevant empirical contributions on corruption's determinants, summarized in Table 1, one should first note the wide consensus in the literature about the existence of some negative correlation between corruption and economic development. Any empirical study on this matter includes, indeed, some proxy for economic development (mostly per capita GDP) among the explanatory variables. In contrast, the other explanatory variables usually vary among studies by different authors. Moreover, it is possible to find factors which change sign and/or statistical significance from one study to another, based on slightly different 
empirical specifications.

-Table 1-

La Porta, Lopez-de-Silanes, Shleifer and Vishny $(1997,1999)$ document for instance the relevance of a country's legal system and religious affiliation in causing corruption; however, the same variables lose statistical significance in the work by Adserà, Boix and Payne (2000) who instead point out how corruption may be significantly lowered by the diffusion of daily newspapers in a democratic context. Also Brunetti and Weder (2003) focus on the negative impact that citizens' information may have on corruption, but only when freedom of information is guaranteed ${ }^{1}$.

Ades and Di Tella (1999) suggest that openness to foreign trade is a primary factor for experiencing relatively low corruption. Leite and Weidmann (1999) achieve similar results for openness by using a different proxy and also point out the positive impact that a country's endowment of natural resources can have on corruption. Treisman (2000), however, documents the fragility of the same variable when controlling for development and uninterrupted democracy.

The role of government decentralization in causing corruption is also object of a ferment debate. On the one hand Fisman and Gatti (2002), among the others, provide evidence of a negative impact on corruption (i.e. fiscal decentralization leads to less corruption); on the other hand Treisman (2000) claims a negative correlation between corruption and a federal dummy. Persson, Tabellini and Trebbi (2001) focus instead on electoral rules; they show how corruption is lower where electoral systems are pure majoritarian, based on single-member district, plurality rule and no voting list. Nevertheless Adserà, Boix and Payne (2000) find the dummy for an electoral system based on proportional representation statistically insignificant. The study by Treisman (2000) seems to be the most exhaustive, for the objective of this work, for he tries to find out what causes corruption by controlling for the most wide set of explanatory factors. The main result of his analysis is the significant impact on corruption of economic development, Protestant religion, British colonial heritage and democracy uninterrupted for a 46 years 
period (1950-1995).

The measurement of corruption increases the difficulty of conducting any empirical study on it. All the available data are perception indexes provided by private firms and international organizations based on surveys of country citizens or business analysts. These values are far from being objective measures. Further, these corruption perception indexes could give even more distort information since the main aim of institutions providing corruption data is to give some country risk assessments to international investors. According to this view, simple corruption perception indexes, produced by individual sources, like BI (Business International), ICRG (International country Risk Guide), WB (World Bank index), WCR (World Competitiveness Report), should be less reliable than aggregate corruption indicators, like CPI (Corruption perception Index by Transparency International) and Graft (by Kaufmann, Kraay and Zoido-Lobatòn, 1998) that, being based on corruption data coming from different sources, include perceptions by citizens as well as by risk analysts and experts² .

After this brief illustraton of how different corruption indicators, samples of countries, and, more importantly, empirical specifications might have driven opposite conclusions reached by previous studies, I look for robust correlations between each explanatory variable and corruption.

\section{Extreme Bounds Analysis: Empirical Methodology}

Edward E. Leamer (1978), in explaining the common estimation approach used by econometricians, reports this emblematic sentence:

"If you torture data long enough, Nature will confess"

(Coase)

Trying several specifications and choosing the one most favorable to the desired empirical result, is exactly what this work wants to avoid. I apply to 16 potential determinants of corruption 
(the same displayed in the first column of Table 1) a "global sensitivity analysis" based on the Leamer's $(1978,1983,1985)$ Extreme Bounds Analysis (EBA) as modified by Levine and Renelt (1992) in their study of growth regressions.

The EBA relies on linear OLS regressions of the following form:

$$
C=\alpha+\beta M+\gamma_{i} \mathbf{I}+\delta_{z} \mathbf{Z}
$$

where the dependent variable is the level of corruption perceived in each country according to the GRAFT index, composed by Kaufmann, Kraay and Zoido-Lobaton (1998), M is the variable of interest that I want to test, $\mathbf{I}$ is a set of basic control variables always included in the regression, while $\mathbf{Z}$ is a set of up to three variables chosen from the most relevant explanatory factors considered by past studies (see table 1). I choose to have per capita income as the only I-variable in the EBA specification, for it has been included in any empirical study on corruption and always found strongly statistically significant ${ }^{3}$.

The EBA consists of estimating $\beta$ by modifying the number and the composition of the conditioning information set $\mathbf{Z}$. If the extreme upper bound and the extreme lower bound of coefficient $\beta$ - respectively defined as the estimated coefficients corresponding to the highest value of $\beta$ plus twice its standard error and the lowest value of $\beta$ minus twice its standard error, result statistically significant (at the conventional level) and with the same sign, the variable $\mathrm{M}$ is considered robust to specification changes ${ }^{4}$. Note that the Extreme-Bounds Analysis does not provide support to any causal links between the dependent variable and the M-variable, even if it results robust; that is, even if a right-hand variable passes the test, it cannot be considered a robust "determinant" of corruption unless there are no doubts about the causality of the correlation identified by the EBA.

This paper also presents an extension of the typical Extreme-Bounds Analysis: the test is for the first time, to the best of my knowledge, applied to vectors of dummies (a legal vector and a 
colonial vector). In this case the sensitivity analysis consists in testing the joint significance of the dummies composing the vector. The estimation steps do not change: the significance of the M-vector (i.e. an F-value larger than the critical value) is studied when changing the conditioning set of variables as described above.

The Extreme Bounds Analysis has been criticized for being a too "draconian" in its way of distinguishing among fragile and robust variables (see Sala-i-Martin, 1997). The most relevant objection concerns the multicollinearity problems involved when adding Z-variables to the base specification. A high correlation between the M-variable and just one Z-variable could indeed induce the loss of significance of $\beta$ whenever the collinear variable is controlled for. Moreover, an extremely volatile sign of $\beta$ could be the result of the presence/absence of the collinear variable/s in the specification.

In order to deal with this problem, I first modify the original Leamer's sensitivity analysis following the suggestions of Levine and Renelt (1992). More in detail, I restrict the number of explanatory variables in the specification model to a maximum of 5 when three Z-variables are added. Further, when testing the robustness of one variable, I drop from the control factors those proxies likely to measure highly related aspects. For example, when I apply the EBA to the dummy for pure majoritarian electoral rule ( $m a j)$ I drop the proxies for the dimension of the electoral district (dismag) and percentage of vote on list (plist).

The most important measure taken to handle multicollinearity is the registration of the number of regressions which show an insignificant estimated coefficient of the M- variable. In this way, sensitivity results for all the variables of interest are easily comparable, making it possible to understand whether one variable did not pass the EBA due to collinearity with one or more control factors or to its "truly fragile" nature. If indeed all or almost all the regressions run lead to an insignificant coefficient we can confidently consider that M-variable as fragile. If the number of insignificant regressions is instead low compared to the total we could mistake the EBA results if we declared $\mathrm{M}$ as fragile before taking a closer look at the Z-variables entering the 
few insignificant regressions. This would make it possible to motivate the failures of the "almost robust" M-variable and, in this way, distinguish between its truly fragile nature and collinearity biases.

As an additional attempt to tackle potential collinearity I finally apply principal component analysis (pca) to two groups of explanatory variables whose correlation with corruption is thought of as capturing the same economic, sociocultural or institutional aspects. I then conduct the EBA on the first component which, as I will explain in the next session, accounts in both cases for more than 65 per cent of the total variance.

\subsection{Data Description}

The analysis is based on cross-country data covering a total of 62 countries, both developed and developing. The sample could have been larger since for some variables more than 62 observations were available, but I choose to restrict the sample in order to have each variable covering the same countries and, therefore, to lower the chance to bias the estimates. Almost all economic, sociocultural and institutional variables used in this study refer to average values over the period 1990-1998.

I test the robustness of 16 variables (shown in the first column of Table 1), for a total of 28 proxies (i.e. $28 \mathrm{M}$ variables) since for some variables I check the results by using alternative measures. For each M-variable the test relies on a total of 299 regressions, with the exception of the 377 regressions for the I-variable. I also consider a vector of legal origin dummies, found by La Porta et al. (1998) to be significantly related to corruption, and a vector of colonial heritage dummies claimed to be highly predictive of corruption by Tresiman (2000).

To measure corruption I employ two aggregate perception indicators: the Corruption Perception Index (CPI) by Transparency International and the Graft Index by Kaufmann, Kraay and Zoido-Lobaton (1999). Both measures are based on single perception indexes computed from 
surveys of business people, local citizens or experts' opinions. The aggregation of corruption values coming from different sources should lower the measurement error intrinsic to any subjective measure.

The primary differences between the 2 indicators is the aggregating methodology. The Graft index aggregates individual corruption indicators by using an unobserved components model which presents the corruption values coming from each source as a linear function of the unobserved component (the existing true corruption) plus a disturbance term which reflects the perception errors and the lack of sample coincidence among individual indicators ${ }^{5}$. The Graft index is based on data coming from 11 institutional sources and it ranges from a minimum of -2.5 (lack of corruption) to a maximum of 2.5 (worst corruption). The CPI is instead constructed as a simple mean of values from individual sources opportunely standardized and equally weighted.

I employ the average value of CPI for the period 1997-1999. In 1997 the CPI is constructed by aggregating corruption data from 6 different sources (for a total of 7 surveys), while in 1998 the sources included are 7 (for a total of 12 surveys) and 10 (for 14 surveys) in 1999. It assumes values ranging from 0 (worst corruption) to 10 (lack of corruption). I rescaled both indicators in order to have higher values associated with higher corruption. It is worth noting that although the CPI and the Graft index are not based on the same number and types of individual corruption indexes and rely on different aggregation methodologies, they appear to be highly correlated ( $\rho=97)$. A strong correlation between indexes is especially important in the context of subjective measures for it is most likely to reflect consistency in the evaluations and individual perceptions coming from different sources ${ }^{6}$.

\section{- I-Variables Data}

The only I-variable included the model is economic development proxied by the logarithm of GDP per capita, adjusted for purchasing power (lyp).

\section{- Economic Data}


Among the economic explanatory variables, the presence of State regulation of the economy is proxied by the "regulatory burden" (reg) constructed by Kaufmann et al. (1999) to take into account the incidence of market-unfriendly policies on illicit rent appropriation. Higher values indicate less government intervention. The endowment of natural resources is measured as the fraction of GDP produced in the Mining and Quarrying sectors (mining).

To test the robustness of a country's openness to foreign trade I consider 3 alternative proxies: the sum of exports and imports of goods and services measured as a share of GDP (trade), the sum of merchandise exports and imports divided by the value of GDP measures in current US dollars (open), and an index compiled by Sachs and Warner (1995) measuring the fraction of years during the period 1950-1994 that the economy has been open, ranging from 0 to 1 scale (yrsopen).

Trade policies and market-unfriendly policies are theoretically related to corruption for similar reasons. The imposition of tariffs or quantitative restricton as well market regulations are indeed thought of as creating more opportunities for rent appropriation by providing public officials a higher discretionary power. A principal component analysis highlighting the common features of the two variables is therefore sensible, in order to reduce collinearity biases potentially generated by the inclusion of both reg and open or yrsopen in the specification. The first component, which I call government intervention (inter) and explains 67 per cent of the variation, is then screened for robustness according to the EBA approach.

\section{- Sociocultural Data}

Protestant religion is measured as the percentage of the population belonging to the Protestant religion in 1980 (prot80). For the ethnolinguistic fragmentation I employ 2 proxies: avelf and ethno. They capture the probability that two randomly selected persons from a given country will not belong to the same ethnolinguistic group; they both range from 0 (homogeneous) to 1 (strongly fractionalized). The level of education is measured as the average educational 
attainment for the population aged 25 and over (school). I conduct the EBA on the five legal origin dummies (British, French, German, Scandinavian, Socialist) introduced by La Porta et al. (1999). I first test the sensitivity of the British legal origin dummy (legor_uk) and then of the legal vector composed by the five dummies. I also check the robustness of the British Colonial heritage dummy $($ col_uk), that Treisman (2000) claims as more significant than the British legal system (legor_uk) in reducing corruption. I finally consider the vector composed by dummies for British $\left(\mathrm{col}_{-} u k\right)$, French $\left(\mathrm{col} \_f r\right)$ and Spanish $\left(\mathrm{col}_{-} e s\right)$ colonial heritage.

\section{- Institutional Data}

To measure the degree of democracy I employ a measure of the respect of basic political rights, polright, constructed by Freedom House (higher values indicate total absence of political liberties) and a dummy for maintaining democratic institutions for a continuous period of 46 years, from 1950 to 1995 (demo). The index ranges between 0 (total freedom) to 100 (total repression).

To test the robustness of electoral rules in causing corruption I consider three variables introduced by Persson, Tabellini and Trebbi (2001). Dismag measures the average number of representatives elected in each district and ranges between 0 (single-member districts) and 1 (a single electoral system); plist indicates the percentage of representatives elected through party list systems with values ranging between 0 (plurality rule in each district) and 1 (fully proportional system), while maj is a dummy variable for an electoral system based on a majority or a plurality rule. The proxy for decentralization of government powers is a federal dummy (federal). The degree of political instability (instab) existing in a country is proxied by the point estimate of Kaufmann et al.(1999)'s "Political Instability and Violence"; higher values correspond to less instability. I also use an objective proxy for political instability, that is the average number of governants per year (leader), considering the period 1980-1993.

The level of mass information is proxied by the diffusion of newspapers (newsp), radio (radio) and television $(t v)$. I also consider an index of freedom of information (freeinfo) produced by 
Freedom House and previously employed by Brunetti and Weder (2003). I finally grouped newsp, radio, telev and freeinfo using principal component analysis in order to take into account their communalities and eliminate potential collinearity biases. I retained the first component, media, and conducted the EBA on it. The Data Appendix describes the data set in more detail; Table 2 presents summary statistics of all the variables discussed above and Table 3 shows the partial correlations among them.

-Table 2 and Table 3-

\section{Sensitivity Analysis' Results}

This section describes the results of the Extreme-Bounds Analysis for each interest variable so far introduced. The empirical estimates are presented by groups of variables, namely economic, sociocultural and institutional factors. Table 4 to Table 8 report the EBA results when employing the Graft index. The estimates with the CPI are similar for almost all the variables and are presented in Table $4 \mathrm{~b}$ to Table $7 \mathrm{~b}$.

\subsection{EBA Estimates for Economic Variables}

- Table 4-

The EBA results for the economic variables, shown on Table 4, suggest that economic development is, as predicted by all previous studies, robustly associated with less corruption. The estimated coefficient of lyp is indeed highly significant in all the regressions run, and maintains a constant negative sign. It could be argued that economic development exerts a major control on corruption, by increasing the chance of identifying and punishing illicit rents appropriations and, thus, lowering the governants' incentives to behave dishonestly. However, not only may economic development reduce corruption but also corruption may slow down the economic development. The latter argument has been widely documented ${ }^{7}$ and is undeniable. Unfortu- 
nately the Extreme-Bounds Analysis can only establish robust linear correlations and therefore cannot solve the causation problem. Future research on causes of corruption should therefore carefully address the endogeneity problem existing in the robust correlation between corruption and economic development ${ }^{8}$.

Previous studies argue that the higher the governmental role in the economic sphere, the more will be the occasions for illicit appropriations of resources by public officials. The EBA shows, however, the fragility of the market regulation proxy (reg). As shown on Table 4, even though reg presents the theoretically expected negative sign (i.e. more corruption associated with more market regulations) its estimated coefficient loses statistical significance in more than 30 per cent of the regressions run. Equally, none of the 3 proxies for openness to foreign competition is robust, and among them only open maintains a constant negative sign, as theoretically expected, but it still loses statistical significance in nearly 40 per cent of the regressions run.

Better results are obtained for the first component retained from the principal component on the trade variables and the regulations index. Inter presents indeed a contsant negative sign and looses significance in 47 out of 232 regressions run. The main cause of this lack of significance in relatively few regressions seems to be the inclusion of the proxy for political instability in the specification. Inter and instab are indeed highly correlated $(\rho=0.72)$; government intervention in the economy appears to be higher the lower political instability is ${ }^{9}$, yet political instability, as we will see later, is robustly negatively related to corruption. Finally, the proxy for endowment of natural resources also comes out as fragile. Our result replicates those of Treisman (2000); the estimated impact of natural endowment on corruption disappears when adopting specification comprehensive of proxies for economic development and uninterrupted democracy.

\subsection{EBA Estimates for Sociocultural Variables}

Recent empirical studies (see La Porta et al., 1997, 1999, and Treisman, 2000) point out the positive or negative impact that different religions may have on corruption. This could be due, 
on the one hand, to the kind of relations existing between State and Church, and, on the other hand, to differences in the faithfuls' respect of social hierarchies, which may lead to diversely tolerate the governants' abuse of public power. I test the robustness of Protestant religion, for it is thought of as the most egalitarian and theoretically least linked with corruption.

\section{-Table 5-}

Table 5 shows that Protestant religion is indeed a robust determinant of corruption; all the 299 regressions run result significant at the 0.05 confidence level. The always negative sign suggests a negative impact on corruption, supporting the theoretical and empirical argumentations by La Porta et al. $(1997,1999)$ and Treisman $(2000)^{10}$. This is one of the most interesting results of this paper: according to the EBA, different religions may have substantially diverse effects on corruption.

The sensitivity analysis for a country's legal origin follows two distinct steps: I first ask whether the British legal origin (legor_uk) is a robust determinant of corruption, and next I consider the legal vector constituted by the five legal dummies (British, German, French, Scandinavian and Socialist) introduced by La Porta et al. (1999). The single dummy legor_uk results fragile even if I drop the British colonial heritage (col_uk) dummy from the Z-variables. Results are in this case slightly better: the estimated coefficient is always negative but still statistical insignificant in 46 out of the 232 the regressions run. However, the insignificant regressions become only 17 when the CPI by Transparency International is used to measure corruption. Looking at these insignificant regressions seems to suggest that countries adopting a common law legal system are less corrupt because they tend to be Protestant and adopt a majoritarian political system ${ }^{11}$.

Next, I consider the impact on corruption of a country's legal origin by extending the EBA to a vector composed by the five legal dummies ${ }^{12}$. The "insignificant regressions" reported in the first row of Table 8 are the regressions that lead to accept the null hypothesis of the five 
dummies' coefficients jointly equal to zero.

-Table 8-

Results seem to confirm the findings obtained for legor_uk. The loss of statistical joint significance of the legal vector 31 regressions (only 18 when the Transparency Index is employed for corruption) is indeed due to the inclusion of the British colonial dummy, the Protestant religion and the majoritarian political system in the empirical specification.

Treisman (2000) claimed that what really matters on corruption is not a country's legal system but its "legal culture", strongly linked with its colonial heritage. The Extreme-Bounds Analysis applied to the British Colonial heritage provides indeed better results compared to the British legal origin's ones. What comes out is that not only does col_uk lose significance in a lower number of regressions than legor_uk but if legor_uk is dropped from the set of Z-variables, col_uk results nearly robust. Only 21 regressions present indeed an insignificant estimated coefficient; moreover, 14 out of 21 are significant at the 0.07 confidence level. Results obtained with the CPI are even better, with col_uk always significant when legor_uk is excluded from the set of Z-variables.

The different EBA results found for the British colonial heritage and the British legal origin suggest that the reason for observing relatively lower levels of corruption in former British colonies goes somehow behind the adoption of a common law legal system, as Treiman (2000) has pointed out. This result is confirmed when the EBA is conducted on the vector composed by the colonial dummies; the colonial vector is indeed significant in all the 299 regressions run, with the British colonial dummy being the only one showing a negative sign. Colonial traditions seem therefore to play a consistently significant role in determing the present level of perceived corruption.

To conclude, Table 5 reports the EBA results for education of the population and ethnolinguistic fragmentation. As it is clear from the number of insignificant regressions and from the sign of the coefficients' bounds, both variables are highly sensitive to changes in the control 
factors included in the empirical specification ${ }^{13}$.

\subsection{EBA Estimates for Institutional Variables}

It is a common belief that incentives and opportunities of generating corruption are strongly linked with political institutions; therefore, the empirical literature on determinants of corruption includes many institutional factors among the potential causes of corruption.

The presence of democratic institutions is one of the main factors considered by past studies on corruption's determinants. On a theoretic viewpoint, illicit governants' behavior can be prevented only when basic political rights are effectively guaranteed to citizens. Unfortunately, it is also true that corrupt governants are more likely to limit the citizens' control on their power through the instrument of vote. Therefore, due to simultaneity problems, even if some proxy for democracy resulted robust, we should not stop wondering about the causal direction of that correlation. According to the EBA, actual democracy (polright) is weakly related with corruption whereas uninterrupted democracy (demo) results highly significant in reducing corruption.

-Table 6-

All the regressions run for demo show indeed a stable negative coefficient, always strongly statistical significant. Therefore what seems to matter for corruption is not the presence of democratic institutions newly legitimated and implemented (polright is indeed fragile), but democratic principles consolidated during a long continuous period (see also Treisman, 2000). In other words, it seems that civic participation to political activities is effective in increasing the risk for corrupt incumbents being caught and punished (i.e. less incentives to illicit rent appropriation) only if democratic institutions are so rooted in a country to make political elections really a mean of control over governants' activities. Note that the use of such a proxy for continuous democratic institutions also removes the simultaneity problem.

It is also a common opinion that every democratic regime should grant some basic rights such 
as freedom of expression and information. Theoretically, if the electorate is not sufficiently and correctly informed, the vote will not be an efficient instrument to control public corruption. However, the three proxies for the degree of mass media diffusion among citizens, radio, $t v$, and newsp, result fragile. Nevertheless, as pointed out by Besley, Burgess and Prat (2002), a proxy for the diffusion of mass media could be a biased measure of citizens' degree of information for it does not consider the lack of freedom normally experienced by journalists. Political pressures on media could in fact inhibit the diffusion of news on corrupt acts, vanishing, in this way the theoretic negative impact of media on corruption. This is why I also check the sensitivity of the freedom of information index ${ }^{14}$. As shown on Table 6, although freeinfo conserves the predicted sign (positive, since freeinfo assumes higher values when freedom is lower), it loses statistical significance in nearly all the regressions run. Unsatisfactory results are also obtained for the first component of the principal component analysis conducted on all the media variables, freedom of information included. The variable media looses indeed statistical significance in almost 40 per cent of the regressions run and presents a volatile sign.

The federal dummy also comes out as fragile. Although its constantly positive sign seems to suggest a positive impact on corruption, its luck of significance in more than 60 per cent of the regressions does not allow us to claim neither a positive nor a negative correlation between this variable and corruption.

In order to estimate the impact of electoral rules on corruption I follow the estimation procedure of the only empirical study (Persson, Tabellini and Trebbi, 2000), to the best of my knowledge, which deeply investigate the effects of different electoral systems on corruption. I first consider two related but distinct dimensions of electoral rules, the electoral district magnitude (dismag) and the percentage of representatives elected on a party list (plist), and then I check the robustness of the dummy for the majoritarian electoral system (maj). As shown on Table 6, none of the proxies maintains a constant sign and/or conserves an acceptable level of statistical significance. One could argue that the electoral rules can affect corruption only if citizens can 
effectively use the instrument of vote, therefore, if I don't control for this, the electoral proxies are not expected to be statistical significant. This is the reason why I also apply the EBA to interactions between a dummy for democracy and all the institutional variables, as I will explain later.

Finally, table 6 reports the high, robust correlation between political instability and corruption. The estimated sign is stable and always negative, as theoretically expected: since higher values of instab mean less political instability, a negative sign suggests indeed that more political instability (low instab) leads to more corruption (high Graft). This result conforms therefore to previous studies, claiming that public officials will decide to behave more opportunistically if there is a high probability of losing their office next period due to political instability. In other words, incumbents will be more corrupt where high instability lowers the probability of future rents appropriation ${ }^{15}$. However, it is also reasonable for corrupt governments to be the cause of high political instability. Unfortunately once again the EBA cannot solve the reverse causality problem, which remains a primary open issue which is possibly left to future research.

\section{- The last check: Interactive Terms}

To further check the relevance of institutional factors in determining corruption I also take as M-variable the interaction between each institutional factor and a dummy for currently being a democracy $\left(\right.$ demo_c $_{\text {) }}$ constructed on the basis of polright, with the value 3 taken as the benchmark. Many political institutions can indeed have some effects on corruption only if political rights are sufficiently guaranteed to citizens. The EBA results for the interactive terms ${ }^{16}$ show the robustness of "freeinfo*democracy", which conserves the predicted positive sign and statistical significance in 213 out of 232 regressions ${ }^{17}$.

\section{-Table $\%$}

This outcome suggests that freedom of information does matter in reducing corruption under condition of political freedom. Also the results for the interaction between electoral district 
magnitude (dismag) and democracy seem to be relevant, especially if compared to the EBA estimates for dismag taken as a single M-variable: the interactive term shows indeed a constant negative sign and looses statistical in relatively fewer regressions. This means that the magnitude of the electoral district could have some effect on reducing corruption only if citizens are given a real control power on governants by means of the electoral consensus. Unfortunately these results do not hold when the Graft index is replaced by the CPI to measure corruption.

\section{Conclusions}

This paper's aim was to test the robustness of previous empirical evidence on corruption's determinants. I addressed this issue by implementing a global sensitivity analysis based on the E. E. Leamer's EBA. Five of the 28 proxies examined reveal to be highly related to perceived corruption. First, richer countries tend to have less corruption then poorest ones. Second, democratic institutions do exert a certain control on corruption only when they have been continuously held for decades. Third, countries characterized by more political instability result to be more corrupt. Fourth, prevalently Protestant countries seem to be less corrupt. Finally colonial heritage appears to be strongly correlated with the current level of corruption, possibly due to the legal cultures inherited from the former colonising countries as suggested by Triesman (2000).

The strong requirements of the EBA procedure provide evidence to believe that these five variables are truly correlated with corruption. The endogeneous nature of economic development, democratic institutions and political instability remains however an open issue left to future research on corruption for the EBA cannot solve the causation problem. Due to collinearity problems, the Extreme-Bounds Analysis does not allow to claim the irrelevance of all the other explanatory variables which resulted fragile. However, we can still be confident on the true fragility of those variables, like endowment of natural resources, ethnolinguistic fragmentation and political rights, which resulted insignificant in all or nearly all the regressions run. 


\section{Notes}

${ }^{1}$ Further efforts in showing the links between corruption and mass media have recently been made by Djankov et al. (2003) and Besley et al. (2002), not shown in Table 1, who underline how media ownership could be crucial in assuring (or preventing) freedom of information.

${ }^{2}$ Knack and Azfar (2000) underline how the choice of countries to assign a value for corruption is mainly driven by the interests of foreign investors. This leads, for most corruption indicators, to small samples of countries, generally representing large markets characterized by low corruption. The CPI and the Graft index, by aggregating individual corruption indicators, result less biased toward larger and less corrupt countries.

${ }^{3}$ In a preliminary analysis I also included a measure of human capital and guarantee of basic political rights among the I-variables. Their lack of significance in nearly all the regressions run motivated their subsequent exclusion from the I- matrix.

${ }^{4}$ See Leamer $(1978,1983)$ and Levine and Renelt (1992) for details.

${ }^{5}$ For more details on the estimation procedure, see Kaufmann, Kraay and Zoido-Lobadon (1999)

${ }^{6}$ The CPI presents however missing data for the following 7 countries: Bangladesh, Dominican Repulic, Gambia, Ghana, Papua New Guinea, Sri Lanka, Trinidad and Tobago. The EBA results employing the CPI could therefore be more biased toward less corrupt countries, compared to those based on the Graft index.

${ }^{7}$ See Mauro (1995) among the others.

${ }^{8}$ Note that Treisman (2000) has already provided evidence for a direct effect of economic development on corruption (whetever the effect of corruption on economic development is) by running 2SLS using the distance from the Equator as instrument for per capita income.

${ }^{9}$ Remember that higher values of instab indicate lower political instability.

${ }^{10}$ The EBA applied to a proxy for Catholic religion (catho80), which is theoretically the most hierarchical religion and theoretically most linked with corruption, gives similar results with the 
opposite sign. High collinearity with prot80 motivates its exclusion from the present analysis.

${ }^{11}$ Note that the inclusion of maj in the regression makes both the coefficients of legor_uk and maj insignificant.

${ }^{12}$ La Porta et al. (1999) distinguish between two main legal system typologies, "common law" and "civil law", based on the assumption that they essentially differ in the relative power of the State and private property owners, and, as a consequence, in the levels of protection granted to individual citizens against abuses of power by public officials. More in detail, distinction is made among British, French, German, Scandinavian and Socialist legal systems.

${ }^{13}$ The loss of statistical significance of ethno-linguistic fragmentation when controlling for per capita income (one of our I-variables) could be explained by argumenting that ethnic fragmentation has only an indirect effect on corruption by means of economic development (see Treisman, 2000).

${ }^{14}$ Following Besley et al. (2002) and Djankov et al. (2003), I also applied the EBA to proxies for state-owned newspapers and tv stations, thought they tend to register "political capture" of the media rather than potential causes of corruption. More in detail, I considered the market share of state-owned newspapers/TV stations out of the five largest daily newspapers/TV stations. However, for these variables the sample used is restricted to only 45 countries. The proxy for state owned tv stations passed the EBA with a significant negative sign. This result confirms what has been pointed out by Besley et al.(2002): state owned media are more likely to hide bad news on the government, such as illicit appropriation of public resources. This would lead to a lower perception of corruption (but not to less corruption!).

${ }^{15}$ Using an objective proxy for political instability - the average number of governants per year (leader) during the period 1980-1993, political instability looses statistical significance in almost all the regressions run though it conserves the expected positive sign.

${ }^{16}$ Table 7 reports the EBA results only for those interactions whose estimates present substantial changes compared to the corresponding not interacted estimates. 
${ }^{17}$ The 20 insignificant regressions indicate the presence of collinearity problems due to the inclusion of instab among the explanatory variables. However the fact that more than 50 regressions with instab entering the specifcation presents a significant coefficient for demo_ $c^{*}$ freeinfo suggests that the resulting negative impact of freedom of information on corruption cannot be thought of as merely driven by its negative correlation with political instability.

\section{References}

[1] Ades, A. and R. Di Tella (1997). National Champions and Corruption: Some Unpleasant Interventionist Arithmetic. The Economic Journal 107(443): 1023-42.

[2] Ades, A. and R. DI Tella (1999). Rents, Competition and Corruption. American Economic Review 89: 982-993.

[3] Adserà A. , C. Boix and M. Payne (2000). Are You Being Served? Political Accountability and Quality of Government. IADP working paper 438.

[4] Besley, T. and R. Burgess (2002). The Political Economy of Government Responsiveness:Theory and Evidence from India. The Quarterly Journal of Economics 117: 1415-1452.

[5] Besley, T., R. Burgess and A. Prat (2002). Mass Media and Political Accountability. Department of Economics working paper, London School of Economics, February.

[6] Brunetti A. and B. Weder (2003).A Free Press is Bad News for Corruption, forthcoming, Journal of Public Economics.check!

[7] Djankov S., C. McLiesh, T. Nenova and A. Shleifer (2003).Who Owns the Media?. Journal of Law and Economics, forthcoming.

[8] Fisman, R. and R. Gatti (2002). Decentralization and Corruption: Cross-Country and CrossState Evidence. Journal of Public Economics 83 (3): 325-345. 
[9] Freedom House (2001). Press Freedom Survey 2001.

[10] Kaufmann D., A. Kraay and P. Loido-Zobatòn (1999). Aggregating Governance Indicators. World Bank working paper 2195.

[11] Kaufmann D., A. Kraay and P. Loido-Zobatòn (1999). Governance Matters. World Bank working paper 2196 .

[12] Kaufmann, D. (1997). Corruption: The Facts. Foreign Policy 107.

[13] Knack S. and O. Azfar (2000). Are Larger Countries Really More Corrupt?. World Bank working paper 2470 .

[14] Lambsdorff, J. G. (1998).Corruption in Comparative Perception. In A. K. Jain (Ed.) The Economics of Corruption. Kluwer Academic Publishers.

[15] Lambsdorff, J. G. (2000). Background Paper to the 2000 Corruption Perceptions Index. Framework Document, Transparency International and Göttingen University.

[16] La Porta R., F. Lopez-de-Silanes, A. Shleifer and R.W. Vishny (1997). Trust in Large Organisations. The American Economic Review, Papers and Proceedings, 87(2): 333-338.

[17] La Porta R., F. Lopez-de-Silanes, A. Shleifer and R.W. Vishny (1999). The Quality of Government. The Journal of Law, Economics and Organization 15: 222-79.

[18] Leamer E. E. (1978). Specification Searches: Ad Hoc Inference from Non-Experimental Data, New York: Wiley.

[19] Leamer, E. E. (1983). Let's take the con out of econometrics. American Economic Review 73(3): 31-43.

[20] Leamer, E. And and L. Herman (1983) "Reporting the Fragility of Regression Estimates", Review of Economics and Statistics, 65: 306-17. 
[21] Leamer, E. E. (1985), "Sensitivity Analysis Would Help", American Economic Review, 75 (5): $31-43$.

[22] Leite, C. and J. Weidmann (1999) Does Mother Nature Corrupt? Natural Resources, Corruption and Economic Growth. IMF working paper, 99/85.

[23] Levine, R. and D. Renelt (1992). A Sensitivity Analysis of Cross-Country Growth Regressions. American Economic Review 82(4): 942-963.

[24] Levine, R. and S. Zervos (1993). Looking at the Facts: What we Know about Policy and Growth from Cross-Country Analysis. World Bank working paper 1115.

[25] Mauro P. (1995). Corruption and Growth. Quarterly Journal of Economics 110: 681-712.

[26] Persson, T. and G. Tabellini (2000). Political Economics: Explaining Economic Policy. MIT Press.

[27] Persson, T., G. Tabellini and F. Trebbi (2003). Electoral Rules and Corruption. Journal of the European Economic Association 1(4): 958-989.

[28] Sala-i-Martin, Xavier (1997). I Just Run Four Million Regressions. NBER working paper 6252.

[29] Tanzi, V. (1998). Corruption Around the World: Causes, Consequences, Scope, and Cures. IMF Staff Papers 45(4).

[30] Treisman, D. (2000). The Causes of Corruption: A Cross-National Study. Journal of Public Economics 76: 399-457.

[31] World Bank (1997-99). World development report. New York, Oxford University Press.

[32] World Bank (2001). World Development Indicators. 


\section{DATA APPENDIX}

\section{Dependent Variable}

GRAFT $=$ proxy for Political and Bureaucratic Corruption built by Kaufmann et al. (1999). The index aggregate individual corruption indicators from eleven different sources by using an unobserved components. Original scores range from -2.5 to 2.5 with higher values corresponding to better outcome. The index is rescaled to have higher values associated to more corruption. Source: Kaufmann et al. (1999), available at www.worldbank.org/wbi/gac.

CPI $=$ proxy for Political Corruption and Bureaucratic Corruption published by Transparency International since 1995. The index employed is the average of the CPI (Corruption Perception Index) over the period 1997-1999. Original scores, ranging from 0 (= completly corrupt) to 10 (= clean) have been rescaled to have higher values associated to more corruption. Source: Transparency International (www.transparency.de) and Internet Center for Corruption Research (www.gwdg.de/ $\sim$ uwvw).

\section{- Economic Variables}

LYP $=$ logarithm of real GDP per capita in constant dollars (international prices, base year 1985). Data trough 1992 are taken from the Penn World Table 5.6, while data on the period 1993-1998 are taken from the Easterly's series available on the World Bank's web site on www.worldbank.org.

MINING $=$ fraction of GDP produced in the Mining and Quarrying sector. Data are for the year 1988 when possible, or the closest available year. The LYP data have been netted out of "mining". Source: Jones C., Hall E. H., QJE (Feb. 1999).

OPEN = proxy for the degree of a country openness to international competition. It is the sum of merchandise exports and imports measured in current U.S. dollar divided by the value of GDP converted to international dollars using purchasing power parity (PPP) rates. Data 
are average for years 1997 and 1998. Source: The World Bank's World Development Indicators (CD-ROM 2000).

$\mathbf{R E G}=$ proxy for the extend of State intervention in economic markets. It is the "Regulatory Burden", the fourth cluster of Kaufmann et. al. (1999)'s governance indicators. It focuses on the government policies including measures of the incidence of market-unfriendly policies such as price controls or inadequate bank supervision, as well as, on perceptions of the burdens imposed by excessive regulation in areas such as foreign trade and business development. It ranges from around -2.5 to around 2.5 with higher values corresponding to better outcome. Source: Kaufmann et al. (1999a.), available at www.worldbank.org/wbi/gac.

TRADE $=$ proxy for the extend of openness to foreign competition. It is the sum of exports and imports of goods and services measured as a share of gross domestic product. Source: The World Bank's World Development Indicators (CD-ROM 2000).

YRSOPEN $=$ proxy for the extent of openness to foreign competition. The index compiled by Sachs and Warner (1995), measures the fraction of years during the period 1950-1994 that the economy has been open and is measured on a $[0,1]$ scale. A country is considered open if it satisfies all of the following criteria: i) nontariff barriers cover less than 40 percent of trade, ii) average tariff rates are less than 40 percent, iii) any black market premium was less than 20 percent during the 1970s and 1980s, iv) the Country is not classified as socialist by Kornai [1992] and v) the government does not monopolize major exports. Source: Jones C., Hall E. H., QJE (Feb. 1999).

\section{- Sociocultural Variables}

AVELF $=$ index of Ethnolinguistic Fractionalization that approximates for the level of lack of ethnic and linguistic cohesion within a country. It ranges from 0 (homogeneous) to 1 (strongly fractionalized) and averages 5 different indexes. The components are: 1) Atlas Narodov Mira, 1960; 2) Muller, 1964; Roberts, 1962; 4) and 5) Gunnemark, 1991. Source: La Porta et al. 
(1998). For Central and Eastern Europe countries computations follow Mauro (1995) with data from Quain (1999).

CATHO80 $=$ percentage of the population belonging to the Roman Catholic religion in 1980. The values are in percent (scale from 0 to 100). Source: La Porta et al. (1999).

COL_(ES, FR, UK) = dummy variable taking the value 1 if the country has been a colony of Spain (or Portugal) (ES), France (FR) or United Kingdom (UK) for a significant time and 0 otherwise. Source: Wacziarg (1996).

ETHNO = index of ethno-linguistic fractionalization that captures the probability that two randomly selected persons from a given country will not belong to the same ethnolinguistic group. Source: Mauro (1995) and Taylor C.L., Hudson M.c., World Handbook of Politcal and Social Indicators II: Cross-National Aggregate Data 1950-1965.

LEGOR_(FR, GE, SC, SO, UK) = dummy variable for the origin of the legal system and, consequently, of the original electoral law for each Country. Five possible origins are considered: Anglo-Saxon Common Law (uk), French Civil Law (fr), German Civil Law (ge), Socialist Law (so), and Scandinavian Law (sc). Source: La Porta et al. (1999).

PROT80 = percentage of the population of each Country belonging to the Protestant religion in 1980. The values are in percent (scale from 0 to 100). Source: La Porta et al. (1999).

SCHOOL $=$ years of schooling (education). Average educational attainment is measured in 1985 for the population aged 25 and over as reported by Barro and Lee (1993). Source: Jones C., Hall E. H., QJE (Feb. 1999).

\section{- Institutional Variables}

DEMO = dummy for continuous democracy from 1950 to 1995 . A country is considered democratic by criteria of Alvarez etal. 1996: (1) the chief executive is elected, (2) the legislature (at least its lower house) is elected, (3) more that one partycontests elections, and (4) during the last three elections of a chief executive there has been at least one turnover of power between 
parties. Data are from Treisman (2000).

DISMAG $=$ electoral district magnitude. It is a measure of the average number of representatives elected in each district. It ranges between 0 and 1 , taking a value of 0 for a system with only single-member districts and close to 1 for a system with a single electoral district. Source: Persson, Tabellini, Trebbi (2000).

FEDERAL = federalism dummy. Source: Boix 2000.

FREEINFO $=$ index of freedom of information provided by Freedom House since 1997 on the basis of the following criteria: 1) laws and regulations that influence media content 2) political influence over media content; 3) economic influence over media content 4) repressive actions which constitute violations of press freedom. Values range from 0 (total freedom) to 100 (total repression). Source: Freedom House.

INSTAB $=$ proxy for the possibility to have wrenching changes in government. It is the point estimate of Kaufmann et al.(1999)'s "Political Instability and Violence", and ranges from around -2.5 to around 2.5 (higher values correspond to less political instability). Source: Kaufmann et al. (1999), available at www.worldbank.org/wbi/gac.

LEADER $=$ number of government leaders in the recent period divided by the length of period in years. Leader is PM in parliamentary systems, president or head of state in presidential or non-democracy. Source Rulers database: http//www.geocities.com/Athens/1058/rulers.html.

$\mathbf{M A J}=$ dummy variable taking the value 1 in presence of either a majority or a plurality rule, 0 otherwise. Only legislative elections are considered. Source: Persson, Tabellini and Trebbi (2001).

NEWSP = Circulation of daily newspapers, where newspapers are journals published at least four times a week. Data are for 1996. Source: World Development Indicators, World Bank.

PLIST $=$ percentage of representatives elected through party list systems. It ranges between 0 (under plurality rule in every district) and 1 (in a system with full proportionality). Source: Persson, Tabellini, Trebbi (2001). 
POLRIGHT $=$ proxy for the extend of respect of basic political rights. The index ranges from 1 (max freedom) to 7 (total absence of political rights). Values are averages of data from 1990/01 to 1998/99 assessments. Source: Freedom house.

RADIO = Number of radio receptors for thousands of inhabitants. Data are for 1999. Source: World Development Indicators, World Bank.

SNEWSP_SH= The market share of state owned newspapers out of the aggregate market share of the five largest daily newspapers (by circulation), 1999. Source: Djankov et al. (2001)

STV_SH= The marjet share of state-owned tv stations out of the aggregate market share of the five largest tv stations (by viewership), 1999. Source: Djankov et al. (2001)

$\mathbf{T V}=$ Number of televisions for thousands of inhabitans. Data are for 1999. Source: International Telecommunication Union (ITU), World Bank. 
Table 1. Main empirical studies on determinants of corruption

\begin{tabular}{|c|c|c|c|c|c|c|c|}
\hline & $\begin{array}{l}\text { Treisman } \\
\text { (2000) }\end{array}$ & $\begin{array}{l}\text { Ades \& Di } \\
\text { Tella } \\
\text { (1999) }\end{array}$ & $\begin{array}{l}\text { La Porta } \\
\text { et al. } \\
\text { (1999) }\end{array}$ & $\begin{array}{l}\text { Fisman \& } \\
\text { Gatti } \\
\text { (2002) }\end{array}$ & $\begin{array}{l}\text { Adserà, Boix } \\
\text { \& Payne } \\
\text { (2000) }\end{array}$ & $\begin{array}{l}\text { Brunetti \& } \\
\text { Weder (2003) }\end{array}$ & $\begin{array}{l}\text { Persson, } \\
\text { Tabellini \& } \\
\text { Trebbi } \\
(\mathbf{2 0 0 1}) \\
\end{array}$ \\
\hline Corruption Index & CPI, BI & WCR, BI & ICRG & $\begin{array}{c}\text { ICRG, } \\
\text { WCR, CPI }\end{array}$ & GRAFT & $\begin{array}{l}\text { ICRG, WB, } \\
\text { CPI }\end{array}$ & CPI \\
\hline $\begin{array}{l}\text { Economic } \\
\text { development }\end{array}$ & -* & -* & $-*$ & $-*$ & $-*$ & - & -* \\
\hline Education & & - & & & & & $-* *$ \\
\hline Political rights & - & + & & & -* & + & - \\
\hline Market regulation & + & & & & & & \\
\hline Natural endowment & + & + & & & & & \\
\hline Openness to trade & - & -* & & - & & $-*$ & -* \\
\hline Protestant religion & $-*$ & & - & & + & & -* \\
\hline $\begin{array}{l}\text { Ethno-linguistic } \\
\text { fragmentation }\end{array}$ & + & & + & + & & + & - \\
\hline British legal system & $-*$ & & -* & & - & & \\
\hline $\begin{array}{l}\text { British Colonial } \\
\text { heritage }\end{array}$ & -* & & & & & & \\
\hline $\begin{array}{l}\text { Uninterrupted } \\
\text { Democracy }\end{array}$ & -* & & & & & & \\
\hline $\begin{array}{l}\text { Freedom of } \\
\text { information }\end{array}$ & & & & & & $-*$ & \\
\hline $\begin{array}{l}\text { Newspaper } \\
\text { circulation }\end{array}$ & & & & & -* & & \\
\hline $\begin{array}{l}\text { Decentralization } \\
\text { (federalism) }\end{array}$ & $+*$ & & & -* & + & & \\
\hline Majoritarian system & & & & & - & & -* \\
\hline Political instability & + & & & & $+*$ & & + \\
\hline
\end{tabular}

Note: + and - indicate the sign of the estimated impact on corruption of each variable of interest. The asterisk refers to statistical significance at the level of 0.05 . 
Table 2. Summary statistics

\begin{tabular}{|c|c|c|c|c|c|}
\hline Variable & Obs. & Mean & Std.Dev. & Min & Max \\
\hline Graft & 62 & -0.45 & 0.98 & -2.12 & 0.96 \\
\hline CPI & 55 & 4.55 & 2.45 & 0.02 & 8.25 \\
\hline avelf & 62 & 0.27 & 0.27 & 0.00 & 0.84 \\
\hline col_uk & 62 & 0.35 & 0.48 & 0 & 1 \\
\hline col_es & 62 & 0.25 & 0.44 & 0 & 1 \\
\hline col_fr & 62 & 0.02 & 0.13 & 0 & 1 \\
\hline demo & 62 & 0.31 & 0.46 & 0 & 1 \\
\hline dismag & 62 & 0.54 & 0.39 & 0 & 0.99 \\
\hline ethno & 59 & 0.35 & 0.27 & 0.01 & 0.9 \\
\hline federal & 62 & 0.18 & 0.39 & 0 & 1 \\
\hline freeinfo & 62 & 34 & 19 & 8 & 74 \\
\hline instab & 62 & 0.32 & 0.83 & -1.62 & 1.69 \\
\hline legor_uk & 62 & 0.39 & 0.49 & 0 & 1 \\
\hline legor_so & 62 & 0.03 & 0.18 & 0 & 1 \\
\hline legor_fr & 62 & 0.45 & 0.50 & 0 & 1 \\
\hline legor_ge & 62 & 0.06 & 0.25 & 0 & 1 \\
\hline legor_sc & 62 & 0.06 & 0.25 & 0 & 1 \\
\hline lyp & 62 & 8.42 & 1.01 & 6.27 & 9.94 \\
\hline maj & 62 & 0.39 & 0.48 & 0 & 1 \\
\hline mining & 62 & 0.05 & 0.08 & 0 & 0.533 \\
\hline newsp & 62 & 144.75 & 143.73 & 0 & 588 \\
\hline open & 62 & 39 & 43.69 & 5.59 & 312.14 \\
\hline plist & 62 & 0.54 & 0.47 & 0 & 1 \\
\hline polright & 62 & 2.57 & 1.45 & 1.01 & 5.57 \\
\hline prot80 & 62 & 16.63 & 25.08 & 0 & 97.08 \\
\hline reg & 62 & 0.58 & 0.42 & -0.34 & 1.24 \\
\hline school & 62 & 5.91 & 2.80 & 0.84 & 12.04 \\
\hline St_n_sh & 46 & 0.13 & 0.29 & 0 & 1 \\
\hline St_tv_sh & 45 & 0.50 & 0.33 & 0 & 1 \\
\hline telev & 62 & 319 & 230 & 3 & 844 \\
\hline trade & 62 & 70.33 & 47 & 17.56 & 343.38 \\
\hline yrsopen & 62 & 0.45 & 0.34 & 0 & 1 \\
\hline
\end{tabular}


Table 3. Simple correlations among variables

\begin{tabular}{|c|c|c|c|c|c|c|c|c|c|c|c|c|c|c|c|c|c|c|c|c|c|c|c|c|c|c|c|c|c|c|c|}
\hline & $\sum_{4}^{\frac{1}{4}}$ & 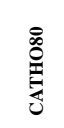 & 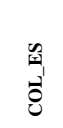 & 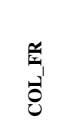 & $\begin{array}{l}y_{1} \\
\text { ơ }\end{array}$ & $\overline{\mathrm{u}}$ & 亶 & 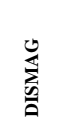 & 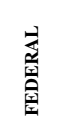 & 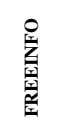 & 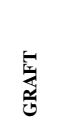 & 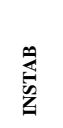 & 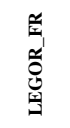 & 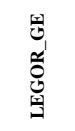 & 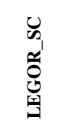 & 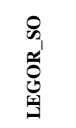 & 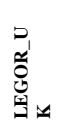 & 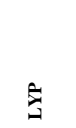 & $\frac{\pi}{2}$ & 产 & $\begin{array}{l}\text { 号 } \\
\sum_{\text {罗 }}\end{array}$ & $\begin{array}{l}\text { zi } \\
\text { 总 }\end{array}$ & $\begin{array}{l}\underline{5} \\
\frac{5}{2}\end{array}$ & 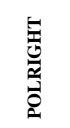 & 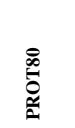 & 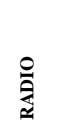 & $\begin{array}{l}0 \\
\text { 过 }\end{array}$ & 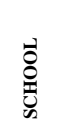 & 恿 & 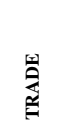 & 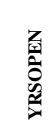 \\
\hline AVELF & 1 & & & & & & & & & & & & & & & & & & & & & & & & & & & & & & \\
\hline САТНОВО & -0.21 & 1 & & & & & & & & & & & & & & & & & & & & & & & & & & & & & \\
\hline COL_ES & -0.07 & 0.65 & 1 & & & & & & & & & & & & & & & & & & & & & & & & & & & & \\
\hline COL_FR & 0.25 & -0.14 & -0.08 & 1 & & & & & & & & & & & & & & & & & & & & & & & & & & & \\
\hline COL_UK & 0.47 & -0.43 & -0.44 & -0.09 & 1 & & & & & & & & & & & & & & & & & & & & & & & & & & \\
\hline CPI & 0.38 & 0.40 & 0.56 & 0.12 & -0.04 & 1 & & & & & & & & & & & & & & & & & & & & & & & & & \\
\hline DEMO & -0.33 & -0.09 & -0.31 & -0.09 & -0.13 & -0.77 & 1 & & & & & & & & & & & & & & & & & & & & & & & & \\
\hline DISMAG & -0.39 & 0.33 & 0.30 & 0.07 & -0.51 & -0.02 & 0.06 & 1 & & & & & & & & & & & & & & & & & & & & & & & \\
\hline FEDERAL & -0.13 & 0.15 & 0.11 & -0.06 & -0.08 & -0.14 & 0.24 & -0.09 & 1 & & & & & & & & & & & & & & & & & & & & & & \\
\hline FREEINFO & 0.38 & -0.18 & 0.13 & 0.00 & 0.30 & 0.56 & -0.59 & -0.15 & -0.19 & 1 & & & & & & & & & & & & & & & & & & & & & \\
\hline GRAFT & 0.38 & 0.28 & 0.46 & 0.09 & 0.05 & 0.97 & -0.78 & -0.09 & -0.20 & 0.57 & 1 & & & & & & & & & & & & & & & & & & & & \\
\hline INSTAB & -0.40 & -0.07 & -0.35 & -0.18 & -0.17 & -0.85 & 0.66 & 0.03 & 0.22 & -0.60 & -0.83 & 1 & & & & & & & & & & & & & & & & & & & \\
\hline LEGOR_FR & -0.22 & 0.67 & 0.65 & 0.14 & -0.54 & 0.53 & -0.25 & 0.45 & -0.08 & 0.03 & 0.37 & -0.29 & 1 & & & & & & & & & & & & & & & & & & \\
\hline LEGOR_GE & -0.17 & -0.02 & -0.15 & -0.03 & -0.19 & -0.25 & 0.25 & 0.13 & 0.39 & -0.27 & -0.27 & 0.34 & -0.24 & 1 & & & & & & & & & & & & & & & & & \\
\hline LEGOR_SC & -0.20 & -0.31 & -0.15 & -0.03 & -0.19 & -0.47 & 0.40 & 0.24 & -0.12 & -0.17 & -0.42 & 0.35 & -0.24 & -0.07 & 1 & & & & & & & & & & & & & & & & \\
\hline LEGOR_SO & -0.15 & 0.09 & -0.11 & -0.02 & -0.14 & 0.26 & -0.12 & 0.07 & -0.08 & -0.10 & -0.02 & 0.16 & -0.17 & -0.05 & -0.05 & 1 & & & & & & & & & & & & & & & \\
\hline LEGOR_UK & 0.47 & -0.55 & -0.47 & -0.10 & 0.79 & -0.16 & -0.03 & -0.67 & -0.02 & 0.22 & -0.02 & -0.11 & -0.72 & -0.21 & -0.21 & -0.15 & 1 & & & & & & & & & & & & & & \\
\hline LYP & -0.60 & -0.03 & -0.22 & -0.18 & -0.30 & -0.80 & 0.71 & 0.24 & 0.38 & -0.59 & -0.83 & 0.72 & -0.11 & 0.33 & 0.30 & 0.00 & -0.21 & 1 & & & & & & & & & & & & & \\
\hline MAJ & 0.38 & -0.45 & -0.33 & -0.10 & 0.58 & -0.07 & -0.12 & -0.87 & -0.02 & 0.22 & 0.02 & -0.01 & -0.47 & -0.17 & -0.21 & -0.15 & 0.72 & -0.24 & 1 & & & & & & & & & & & & \\
\hline MINING & 0.20 & -0.10 & 0.00 & -0.07 & 0.30 & 0.09 & -0.23 & -0.31 & -0.05 & 0.03 & 0.14 & -0.05 & -0.16 & -0.12 & -0.08 & -0.01 & 0.26 & -0.20 & 0.30 & 1 & & & & & & & & & & & \\
\hline NEWSP & -0.45 & -0.28 & -0.25 & -0.13 & -0.26 & -0.73 & 0.62 & 0.22 & 0.19 & -0.40 & -0.74 & 0.68 & -0.30 & 0.43 & 0.56 & 0.01 & -0.20 & 0.78 & -0.19 & -0.21 & 1 & & & & & & & & & & \\
\hline OPEN & -0.10 & -0.16 & -0.28 & -0.05 & 0.14 & -0.53 & 0.33 & 0.13 & 0.02 & -0.07 & -0.54 & 0.51 & -0.23 & 0.12 & 0.18 & -0.07 & 0.10 & 0.46 & 0.05 & -0.05 & 0.46 & 1 & & & & & & & & & \\
\hline PLIST & -0.37 & 0.42 & 0.28 & 0.01 & -0.49 & 0.02 & 0.14 & 0.89 & -0.04 & -0.21 & -0.05 & 0.02 & 0.43 & 0.06 & 0.26 & 0.09 & -0.63 & 0.20 & -0.93 & -0.26 & 0.15 & -0.01 & 1 & & & & & & & & \\
\hline POLRIGHT & 0.59 & -0.13 & 0.14 & 0.16 & 0.37 & 0.62 & -0.66 & -0.21 & -0.15 & 0.83 & 0.65 & -0.68 & 0.04 & -0.25 & -0.27 & -0.12 & 0.27 & -0.74 & 0.29 & -0.01 & -0.58 & -0.12 & -0.30 & 1 & & & & & & & \\
\hline PROT80 & -0.05 & -0.43 & -0.33 & -0.09 & 0.05 & -0.59 & 0.48 & -0.07 & 0.03 & -0.32 & -0.47 & 0.41 & -0.48 & 0.08 & 0.76 & -0.04 & 0.09 & 0.29 & 0.03 & 0.15 & 0.49 & 0.18 & 0.01 & -0.34 & 1 & & & & & & \\
\hline RADIO & -0.40 & -0.15 & -0.23 & -0.14 & -0.17 & -0.70 & 0.76 & -0.03 & 0.33 & -0.57 & -0.72 & 0.67 & -0.29 & 0.21 & 0.38 & 0.01 & -0.01 & 0.71 & -0.01 & -0.23 & 0.68 & 0.26 & 0.02 & -0.62 & 0.52 & 1 & & & & & \\
\hline REG & -0.51 & 0.11 & -0.13 & -0.28 & -0.15 & -0.70 & 0.57 & 0.24 & 0.12 & -0.54 & -0.72 & 0.66 & -0.03 & 0.12 & 0.26 & 0.06 & -0.18 & 0.72 & -0.20 & -0.12 & 0.57 & 0.45 & 0.23 & -0.62 & 0.29 & 0.64 & 1 & & & & \\
\hline SCHOOL & -0.45 & -0.08 & -0.20 & -0.16 & -0.22 & -0.79 & 0.73 & 0.15 & 0.26 & -0.62 & -0.77 & 0.69 & -0.25 & 0.21 & 0.38 & 0.24 & -0.13 & 0.81 & -0.19 & -0.17 & 0.73 & 0.26 & 0.19 & -0.73 & 0.44 & 0.78 & 0.70 & 1 & & & \\
\hline TELEVISION & -0.52 & -0.07 & -0.29 & -0.16 & -0.33 & -0.76 & 0.71 & 0.13 & 0.30 & -0.62 & -0.81 & 0.73 & -0.15 & 0.30 & 0.34 & 0.08 & -0.19 & 0.88 & -0.17 & -0.30 & 0.77 & 0.27 & 0.16 & -0.75 & 0.37 & 0.81 & 0.68 & 0.83 & 1 & & \\
\hline TRADE & 0.11 & -0.19 & -0.20 & -0.01 & 0.36 & -0.22 & -0.01 & -0.03 & -0.12 & 0.22 & -0.18 & 0.22 & -0.18 & -0.09 & -0.02 & -0.04 & 0.25 & 0.08 & 0.24 & 0.08 & 0.10 & 0.83 & -0.18 & 0.21 & -0.01 & -0.05 & 0.15 & -0.07 & -0.13 & 1 & \\
\hline YRSOPEN & -0.30 & -0.06 & -0.22 & -0.17 & -0.22 & -0.62 & 0.54 & 0.18 & 0.24 & -0.36 & -0.64 & 0.60 & -0.07 & 0.29 & 0.25 & -0.18 & -0.14 & 0.68 & -0.05 & -0.17 & 0.54 & 0.48 & 0.07 & -0.43 & 0.21 & 0.57 & 0.57 & 0.50 & 0.62 & 0.26 & 1 \\
\hline
\end{tabular}


Table 4. EBA results for economic variables

Dependent variable: Corruption measured by the Graft index.

\begin{tabular}{|c|c|c|c|c|c|c|}
\hline Variable of Interest (M) & $\beta$ & $\begin{array}{c}\text { St. } \\
\text { Error }\end{array}$ & T-Stat & $\mathbf{R}^{2}$ & Z-Variables & N. Insignificant \\
\hline \multicolumn{7}{|l|}{ Per capita income (lyp) } \\
\hline \multirow[t]{2}{*}{ High-bound } & -0.34 & 0.10 & -3.28 & 0.81 & School, reg, instab & \multirow{3}{*}{$\mathbf{0} / 377$} \\
\hline & & & & & & \\
\hline Low-bound & -0.93 & 0.07 & -12.95 & 0.76 & Col_uk, federal, maj & \\
\hline \multicolumn{7}{|l|}{ Mkt regulation (reg) } \\
\hline High-bound & -0.18 & 0.21 & -0.89 & 0.82 & School, federal, instab & \multirow{3}{*}{106 / 299} \\
\hline Base & -0.60 & 0.23 & -2.62 & 0.72 & & \\
\hline Low-bound & -0.67 & 0.22 & -3.02 & 0.75 & Mining, avelf & \\
\hline \multicolumn{7}{|c|}{ Natural endowment (mining) } \\
\hline High-bound & 1.09 & 0.93 & 1.18 & 0.76 & Col_uk, maj, polright & \multirow{3}{*}{299 / 299} \\
\hline Base & -0.38 & 0.92 & -0.41 & 0.69 & & \\
\hline Low-bound & -0.53 & 0.94 & -0.56 & 0.72 & Polright,federal, freeinfo & \\
\hline \multicolumn{7}{|l|}{ Openness to trade (trade) } \\
\hline High-bound & 0.001 & 0.001 & 0.83 & 0.84 & Col_uk, instab, polright & \multirow{3}{*}{244 / 299} \\
\hline Base & -0.002 & 0.001 & -1.66 & 0.70 & & \\
\hline Low-bound & -0.004 & 0.002 & -2.50 & 0.75 & Mining, polright, school & \\
\hline \multicolumn{7}{|l|}{ Openness to trade (open) } \\
\hline High-bound & -0.0001 & 0.001 & -0.07 & 0.85 & Col_uk, federal, instab & \multirow{3}{*}{125 / 299} \\
\hline Base & -0.004 & 0.001 & -2.53 & 0.72 & & \\
\hline Low-bound & -0.006 & 0.001 & -3.55 & 0.77 & Mining, polright, school & \\
\hline \multicolumn{7}{|c|}{ Openness to trade (yrsopen) } \\
\hline High-bound & 0.03 & 0.230 & 0.12 & 0.83 & Reg, avelf, instab & \multirow{3}{*}{292 / 299} \\
\hline Base & -0.39 & 0.278 & -1.40 & 0.70 & & \\
\hline Low-bound & -0.48 & 0.273 & -1.75 & 0.73 & Mining, polright, school & \\
\hline \multicolumn{7}{|c|}{ Govt. intervention ( $1^{\text {st }}$ component) } \\
\hline High-bound & -0.07 & 0.075 & -0.99 & 0.82 & Federal, instab, polright & \multirow{3}{*}{47 / 232} \\
\hline Base & -0.24 & 0.072 & -3.31 & 0.74 & & \\
\hline Low-bound & -0.26 & 0.073 & -3.54 & 0.75 & Mining, polright & \\
\hline
\end{tabular}

Note:

The base $\beta$ is the estimated coefficient from the base regression with the variable of interest $(\mathrm{M})$ and the always included $I-$ Variable, lyp. The High - Bound $\beta$ is the estimated coefficient corresponding to the regression that leads to the extreme high bound. The Low-Bound $\beta$ is the estimated coefficient corresponding to the regression that leads to the extreme low bound. The $\mathrm{Z}-$ Variables displayed are the control variables included in the regressions that produce the extreme bounds. N. Insignificant indicates the number of regressions with the estimated coefficient statistically insignificant at the .05 confidence level. 
Table 5. EBA results for socio-cultural variables Dependent Variable: Corruption measured by the Graft index

\begin{tabular}{|c|c|c|c|c|c|c|}
\hline Variable of Interest (M) & $\beta$ & $\begin{array}{l}\text { St. } \\
\text { Error }\end{array}$ & T-Stat & $\mathbf{R}^{2}$ & Z-Variables & $\begin{array}{c}\mathrm{N} . \\
\text { Insignificant }\end{array}$ \\
\hline \multicolumn{7}{|c|}{ Protestant religion (Prot80) } \\
\hline High-bound & -0.004 & 0.002 & -2.08 & 0.85 & Col_uk, instab, school & \\
\hline Base & -0.01 & 0.002 & -3.81 & 0.75 & & 0 / 232 \\
\hline Low-bound & -0.01 & 0.002 & -3.98 & 0.78 & Mining, trade & \\
\hline \multicolumn{7}{|c|}{ British legal system (legor_uk) } \\
\hline High-bound & -0.008 & 0.27 & -0.03 & 0.74 & Col_uk, catho80, maj & \\
\hline Base & -0.41 & 0.14 & -2.93 & 0.73 & & 115 / 299 \\
\hline Low-bound & -0.45 & 0.16 & -2.81 & 0.84 & Mining, maj, instab & \\
\hline \multicolumn{7}{|l|}{ Legor_uk (without col_uk) } \\
\hline \multirow[t]{2}{*}{ High-bound } & -0.02 & 0.20 & -0.98 & 0.76 & Avelf, maj, school & \\
\hline & & & & & & 46 / 232 \\
\hline Low-bound & -0.45 & 0.16 & -2.81 & 0.84 & Maj, mining, instab & \\
\hline \multicolumn{7}{|c|}{ British colonial heritage (col_uk) } \\
\hline High-bound & -0.16 & 0.24 & -0.68 & 0.77 & Legor_uk, reg, trade & \\
\hline Base & -0.46 & 0.14 & -3.19 & 0.73 & & 88 / 299 \\
\hline Low-bound & -0.41 & 0.24 & -0.73 & 0.75 & Legor_uk, mining, polright & \\
\hline \multicolumn{7}{|l|}{ Col_uk (without legor_uk) } \\
\hline High-bound & -0.22 & 0.17 & -1.29 & 0.77 & Reg, avelf, maj & \\
\hline Base & & & & & & $21 / 232^{\circ}$ \\
\hline Low-bound & -0.55 & 0.15 & -3.57 & 0.75 & Mining, polright & \\
\hline \multicolumn{7}{|l|}{ Education (school) } \\
\hline High-bound & -0.012 & 0.037 & -0.34 & 0.83 & Reg, prot80, imstab & \\
\hline Base & -0.10 & 0.041 & -2.41 & 0.72 & & 184 / 299 \\
\hline Low-Bound & -0.12 & 0.041 & -2.97 & 0.74 & Mining, trade & \\
\hline \multicolumn{7}{|c|}{$\begin{array}{l}\text { Ethno-linguistic fragmentation } \\
\text { (avelf) }\end{array}$} \\
\hline High-bound & -0.14 & 0.32 & -0.42 & 0.78 & Legor_uk, prot80, trade & \\
\hline Base & -0.63 & 0.33 & -1.94 & 0.71 & & 215 / 299 \\
\hline Low-bound & -0.85 & 0.33 & -2.60 & 0.75 & Reg, mining, polright & \\
\hline \multicolumn{7}{|c|}{$\begin{array}{l}\text { Ethno-linguistic fragmentation } \\
\text { (ethno) }\end{array}$} \\
\hline High-bound & -0.000 & 0.003 & -0.009 & 0.75 & Legor_uk, maj, school & \\
\hline Base & -0.005 & 0.003 & -1.74 & 0.70 & & 232 / 299 \\
\hline Low-bound & -0.006 & 0.003 & -2.18 & 0.73 & Federal, maj, polright & \\
\hline
\end{tabular}

Note: The base $\beta$ is the estimated coefficient from the base regression with the variable of interest (M) and the always included I-Variable, lyp. The High - Bound $\beta$ is the estimated coefficient corresponding to the regression that leads to the extreme high bound. The Lowbound $\beta$ is the estimated coefficient corresponding to the regression that leads to the extreme low bound. The $\mathrm{Z}-$ Variables displayed are the control variables included in the regressions that produce the extreme bounds. N. Insignificant indicates the number of regressions with the estimated coefficient statistically insignificant at the .05 confidence level.

- 14 of the 21 insignificant regressions are significant at the $7 \%$ level. 
Table 6. EBA results for institutional variables

Dependent Variable: Corruption measured by the Graft index

\begin{tabular}{|c|c|c|c|c|c|c|}
\hline Variable of Interest (M) & $\beta$ & $\begin{array}{l}\text { St. } \\
\text { Error }\end{array}$ & T-Stat & $\mathbf{R}^{2}$ & Z-variables & $\begin{array}{c}\text { N. } \\
\text { Insignificant }\end{array}$ \\
\hline \multicolumn{7}{|l|}{ Political rights (polright) } \\
\hline High-bound & 0.17 & 0.08 & 2.07 & 0.74 & Mining, trade, avelf & \multirow{3}{*}{$290 / 299$} \\
\hline Base & -0.05 & 0.073 & 0.069 & 0.70 & & \\
\hline Low-bound & -0.13 & 0.11 & -1.20 & 0.74 & School, freeinfo, federal & \\
\hline \multicolumn{7}{|c|}{ Uninterrupted democracy (demo) } \\
\hline High-bound & -0.37 & 0.17 & -2.18 & 0.86 & Legor_uk, prot80, instab & \multirow{3}{*}{0 / 299} \\
\hline Base & -0.80 & 0.19 & -4.17 & 0.76 & & \\
\hline Low-bound & -0.88 & 0.20 & -4.42 & 0.78 & Mining, federal & \\
\hline \multicolumn{7}{|l|}{ Radio diffusion (radio) } \\
\hline High-bound & -0.0000 & 0.0002 & -0.27 & 0.78 & School, prot80, maj & \multirow{3}{*}{159 / 299} \\
\hline Base & -0.0006 & 0.0002 & -2.76 & 0.72 & & \\
\hline Low-bound & -0.0007 & 0.0002 & -3.11 & 0.75 & Mining, federal, polright & \\
\hline \multicolumn{7}{|c|}{ Newspaper readership (newsp) } \\
\hline High-bound & 0.0002 & 0.0007 & 0.28 & 0.82 & Prot80, mining, instab & \multirow{3}{*}{157 / 299} \\
\hline Base & -0.002 & 0.0007 & -2.12 & 0.71 & & \\
\hline Low-bound & -0.002 & 0.0008 & -2.13 & 0.71 & Mining, polright & \\
\hline \multicolumn{7}{|l|}{ Television diffusion (tv) } \\
\hline High-bound & -0.0002 & 0.0006 & -0.31 & 0.82 & Mining, prot80, instab & \multirow{3}{*}{144 / 299} \\
\hline Base & -0.001 & 0.0006 & -2.21 & 0.71 & & \\
\hline Low-bound & -0.002 & 0.0007 & -3.69 & 0.76 & mining, trade & \\
\hline \multicolumn{7}{|c|}{ Freedom of information (freeinfo) } \\
\hline High-bound & 0.011 & 0.007 & 1.57 & 0.72 & Mining, polright, federal & \multirow{3}{*}{254 / 299} \\
\hline Base & 0.006 & 0.005 & 1.37 & 0.70 & & \\
\hline Low-bound & -0.002 & 0.004 & -0.58 & 0.81 & Reg, school, instab & \\
\hline \multicolumn{7}{|l|}{ Media ( $1^{\text {st }}$ component) } \\
\hline High-bound & 0.012 & 0.09 & 0.13 & 0.82 & Prot80, school, instab & \multirow{3}{*}{$81 / 299$} \\
\hline Base & -0.26 & 0.08 & -3.33 & 0.74 & & \\
\hline Low-bound & -0.035 & 0.08 & -4.06 & 0.78 & Mining, trade, polright & \\
\hline \multicolumn{7}{|l|}{ Federalism (federal) } \\
\hline High-bound & 0.37 & 0.20 & 1.80 & 0.72 & Mining, freeinfo, polright & \multirow{3}{*}{$211 / 299$} \\
\hline Base & 0.32 & 0.19 & 1.66 & 0.70 & & \\
\hline Low-bound & 0.15 & 0.20 & 0.74 & 0.74 & Reg, trade, polright & \\
\hline \multicolumn{7}{|c|}{ Electoral district magnitude (dismag) } \\
\hline High-bound & 0.43 & 0.19 & 2.31 & 0.75 & Mining, federal, reg & \multirow{3}{*}{$265 / 299$} \\
\hline Base & 0.31 & 0.18 & 1.69 & 0.70 & & \\
\hline Low-bound & -0.36 & 0.19 & -1.84 & 0.84 & Legor_uk, instab, trade & \\
\hline \multicolumn{7}{|l|}{$\%$ vote on list (plist) } \\
\hline High-bound & 0.35 & 0.16 & 2.21 & 0.74 & Mining, polright, reg & \\
\hline Base & 0.25 & 0.15 & 1.65 & 0.70 & & $260 / 299$ \\
\hline Low-bound & -0.22 & 0.15 & -1.47 & 0.84 & Legor_uk, polright, instab & \\
\hline Majoritarian electoral ru & & & & & & \\
\hline High-bound & 0.11 & 0.17 & 0.66 & 0.83 & Legor_uk, polright, instab & \\
\hline Base & -0.38 & 0.14 & -2.61 & 0.72 & & 124 / 299 \\
\hline Low-bound & -0.44 & 0.15 & -2.86 & 0.73 & Mining, polright & \\
\hline Political instability (insta & & & & & & \\
\hline High-bound & -0.39 & 0.10 & -3.87 & 0.84 & Reg, prot80, maj & \\
\hline Base & -0.56 & 0.10 & -5.75 & 0.80 & & 0 / 299 \\
\hline Low-bound & -0.61 & 0.11 & -5.38 & 0.81 & Polright, trade, federal & \\
\hline Political instability (leade & & & & & & \\
\hline High-bound & 0.11 & 0.30 & 0.38 & 0.81 & Trade, prot80, maj & \\
\hline Base & 0.48 & 0.34 & 1.40 & 0.70 & & $281 / 299$ \\
\hline Low-bound & 0.59 & 0.33 & 1.77 & 0.76 & Reg, school, polright & \\
\hline
\end{tabular}


Table 7. EBA results for interaction terms Dependent Variable: Corruption measured by the Graft index.

\begin{tabular}{lccccc}
\hline Variable of Interest (M) & $\beta$ & $\begin{array}{c}\text { St. } \\
\text { Error }\end{array}$ & T-Stat & $\mathbf{R}^{2}$ & Z-Variables \\
\hline Democracy*maj & & & & & N. \\
Insignificant
\end{tabular}

Note:

The base $\beta$ is the estimated coefficient from the base regression consisting, in this case, of the interactive term of interest (M), lyp (I-Variable) and the variables in the interactive term taken as single factors. The High - Bound $\beta$ is the estimated coefficient of $\mathrm{M}$ corresponding to the regression that leads to the extreme high bound. The Low-Bound $\beta$ is the estimated coefficient of M corresponding to the regression that leads to the extreme low bound. The Z-Variables displayed in the sixth column are the control variables included in the regressions that produce the extreme bounds. N. Insignificant indicates the number of regressions with the estimated coefficient statistically insignificant at the 0.05 level. 
Danila Serra

Table 8. EBA applied to vectors of dummies

\begin{tabular}{lcc}
\hline Vector of interest (M) & \multicolumn{1}{c}{ Measure of corruption } \\
\hline Vector for the legal system & Graft & \\
\cline { 2 - 3 } N. insignificant & $31 / 299$ & $18 / 299$ \\
Vector for the colonial heritage & & \\
N. insignificant & & $\mathbf{0} / 232$ \\
\hline
\end{tabular}

Note: $N$. Insignificant indicates the number of regressions which present the F-value for the vector of interest higher than the critical F-value. 
Table 4b. EBA results for economic variables

Dependent Variable: Corruption measured by the CPI 97-99

\begin{tabular}{|c|c|c|c|c|c|c|}
\hline Variable of Interest (M) & $\beta$ & $\begin{array}{c}\text { St. } \\
\text { Error }\end{array}$ & T-Stat & $\mathbf{R}^{2}$ & Z -Variables & $\begin{array}{c}\text { N. } \\
\text { Insignificant }\end{array}$ \\
\hline \multicolumn{7}{|l|}{ Per capita income (lyp) } \\
\hline \multirow[t]{2}{*}{ High-bound } & -0.74 & 0.30 & -2.42 & 0.77 & Reg, school, instab & \\
\hline & & & & & & 0/377 \\
\hline Low-bound & -2.49 & 0.26 & -9.70 & 0.70 & Mining, avelf, Federal & \\
\hline \multicolumn{7}{|l|}{ Market regulation (reg) } \\
\hline High-bound & -0.31 & 0.63 & -0.50 & 0.78 & School, Federal, Instab & \\
\hline Base & -1.67 & 0.65 & -2.59 & 0.68 & & 87 / 299 \\
\hline Low-bound & -1.86 & 0.63 & -2.96 & 0.71 & Avelf & \\
\hline \multicolumn{7}{|l|}{ Natural endowment (mining) } \\
\hline High-bound & 0.46 & 2.58 & 0.18 & 0.73 & Col_uk, Maj, Polright & \\
\hline Base & -3.97 & 2.61 & -1.52 & 0.65 & & $292 / 299$ \\
\hline Low-Bound & -5.53 & 2.53 & -2.19 & 0.72 & Freeinfo, Federal, Polright & \\
\hline \multicolumn{7}{|l|}{ Openness to trade (trade) } \\
\hline High-bound & 0.002 & 0.004 & 0.49 & 0.78 & Polright, Federal, Instab & \\
\hline Base & -0.07 & 0.004 & -1.69 & 0.66 & & $216 / 299$ \\
\hline Low-bound & -0.01 & 0.004 & -2.99 & 0.73 & Freeinfo, school & \\
\hline \multicolumn{7}{|l|}{ Openness to trade (open) } \\
\hline High-bound & -0.001 & 0.005 & -0.27 & 0.78 & Polright, Federal, Instab & \\
\hline Base & -0.012 & 0.005 & -2.48 & 0.68 & & $113 / 299$ \\
\hline Low-bound & -0.017 & 0.004 & -3.93 & 0.76 & Freeinfo, school & \\
\hline \multicolumn{7}{|l|}{ Openness to trade (yrsopen) } \\
\hline High-bound & -0.25 & 0.68 & -0.37 & 0.79 & Avelf, Maj, Instab & \\
\hline Base & -0.94 & 0.82 & -1.15 & 0.65 & & $299 / 299$ \\
\hline Low-bound & -1.36 & 0.78 & -1.75 & 0.70 & School & \\
\hline \multicolumn{7}{|c|}{ Govt. intervention ( $1^{\text {st }}$ component) } \\
\hline High-bound & -0.10 & 0.22 & -0.47 & 0.78 & Polright, Federal, Instab & \\
\hline Base & -0.63 & 0.20 & -3.14 & 0.70 & & 49 / 232 \\
\hline Low-bound & -0.70 & 0.18 & -3.77 & 0.75 & Freeinfo, school & \\
\hline
\end{tabular}

Note:

The base $\beta$ is the estimated coefficient from the base regression with the variable of interest (M) and the always included $I-$ Variable lyp. The High - Bound $\beta$ is the estimated coefficient corresponding to the regression that leads to the extreme high bound. The Low-Bound $\beta$ is the estimated coefficient corresponding to the regression that leads to the extreme low bound. The $\mathrm{Z}-$ Variables displayed are the control variables included in the regressions that produce the extreme bounds. N. Insignificant indicates the number of regressions which present the estimated coefficient $\beta$ statistically insignificant at the .05 confidence level. 
Table 5b. EBA results for socio-cultural variables Dependent Variable: Corruption measured by the CPI 97-99

\begin{tabular}{|c|c|c|c|c|c|c|}
\hline Variable of Interest (M) & $\beta$ & $\begin{array}{c}\text { St. } \\
\text { Error }\end{array}$ & T-Stat & $\mathbf{R}^{2}$ & Z -Variables & $\begin{array}{c}\mathrm{N} . \\
\text { Insigniicant }\end{array}$ \\
\hline \multicolumn{7}{|l|}{ Protestant religion (prot80) } \\
\hline High-bound & -0.03 & 0.007 & -3.83 & 0.82 & School, Mining, Instab & \multirow{3}{*}{0 / 299} \\
\hline Base & -0.04 & 0.007 & -5.32 & 0.77 & & \\
\hline Low-bound & -0.04 & 0.007 & -5.24 & 0.77 & Polright & \\
\hline \multicolumn{7}{|l|}{ British legal system (legor_uk) } \\
\hline High-bound & -0.20 & 0.72 & -0.29 & 0.75 & Col_uk, School, Maj & \multirow{3}{*}{88 / 299} \\
\hline Base & -1.37 & 0.39 & -3.51 & 0.71 & & \\
\hline Low-bound & -1.53 & 0.38 & -4.00 & 0.74 & Federal, Polright & \\
\hline \multicolumn{7}{|l|}{ Legor_uk (without col_uk) } \\
\hline High-bound & -0.82 & 0.53 & -1.54 & 0.75 & School, Trade, Maj & \multirow{3}{*}{$17 / 232$} \\
\hline Base & -1.37 & 0.39 & -3.51 & 0.71 & & \\
\hline Low-Bound & -1.53 & 0.38 & -4.00 & 0.74 & Polright, Federal & \\
\hline \multicolumn{7}{|c|}{ British colonial heritage (col_uk) } \\
\hline High-bound & -0.49 & 0.67 & -0.73 & 0.75 & Reg, Trade, Legor_uk & \multirow{3}{*}{$69 / 299$} \\
\hline Base & -1.45 & 0.41 & -3.56 & 0.71 & & \\
\hline Low-Bound & -1.12 & 0.66 & -1.70 & 0.74 & Legor_uk, Avelf, Freeinfo & \\
\hline \multicolumn{7}{|l|}{ Col_uk (without legor_uk) } \\
\hline High-bound & -0.89 & 0.48 & -1.85 & 0.75 & Reg, Avelf, Maj & \multirow{3}{*}{ 0/ 232} \\
\hline Base & -1.45 & 0.41 & -3.56 & 0.71 & & \\
\hline Low-Bound & -1.60 & 0.41 & -3.86 & 0.72 & Polright & \\
\hline \multicolumn{7}{|l|}{ Education (school) } \\
\hline High-bound & 0.01 & 0.10 & 0.10 & 0.82 & Reg, Prot80, Instab & \multirow{3}{*}{$141 / 299$} \\
\hline Base & -0.29 & 0.11 & -2.59 & 0.68 & & \\
\hline Low-Bound & -0.34 & 0.12 & -2.93 & 0.73 & Polright, Mining, Trade & \\
\hline \multicolumn{7}{|c|}{ Ethno-linguistic fragmentation (Avelf) } \\
\hline High-bound & -0.21 & 1.30 & -0.20 & 0.71 & Trade, legor_uk & \multirow{3}{*}{$223 / 299$} \\
\hline Base & -1.63 & 0.98 & -1.66 & 0.66 & & \\
\hline Low-bound & -2.24 & 0.96 & 2.34 & 0.72 & Polright, reg, federal & \\
\hline \multicolumn{7}{|c|}{ Ethno-linguistic fragmentation (Ethno) } \\
\hline High-bound & 0.004 & 0.009 & 0.51 & 0.75 & School, Legor_uk,Maj & \multirow{3}{*}{286 / 299} \\
\hline Base & -0.01 & 0.009 & -1.41 & 0.65 & & \\
\hline Low-bound & -0.02 & 0.009 & -2.02 & 0.71 & Polright, trade federal & \\
\hline
\end{tabular}


Table 6b. EBA Results for Institutional Variables

Dependent Variable: Corruption measured by the CPI 97-99

\begin{tabular}{|c|c|c|c|c|c|c|}
\hline Variable of Interest (M) & $\beta$ & $\begin{array}{c}\text { St. } \\
\text { Error }\end{array}$ & T-Stat & $\mathbf{R}^{2}$ & Z-Variables & $\begin{array}{c}\mathrm{N} . \\
\text { Insignificant }\end{array}$ \\
\hline \multicolumn{7}{|l|}{ Political rights (polright) } \\
\hline High-bound & 0.50 & 0.21 & 2.30 & 0.73 & Trade, Avelf, Maj & \multirow{3}{*}{$290 / 299$} \\
\hline Base & 0.11 & 0.21 & 0.55 & 0.64 & & \\
\hline Low-bound & -0.66 & 0.31 & -2.11 & 0.72 & Mining, Freeinfo, Federal & \\
\hline \multicolumn{7}{|c|}{ Uninterrupted democracy (demo) } \\
\hline High-bound & -0.86 & 0.50 & -1.71 & 0.83 & Legor_uk, Prot80, Freeinfo & \multirow{3}{*}{0 / 299} \\
\hline Base & -2.11 & 0.53 & -3.99 & 0.72 & & \\
\hline Low-bound & -2.44 & 0.54 & -4.47 & 0.75 & Mining, Polright & \\
\hline \multicolumn{7}{|c|}{ Freedom of information (freeinfo) } \\
\hline High-bound & 0.05 & 0.02 & 2.60 & 0.72 & Mining,Polright, Federal & \multirow{3}{*}{$203 / 299$} \\
\hline Base & 0.02 & 0.01 & 1.57 & 0.65 & & \\
\hline Low-bound & -0.002 & 0.01 & -0.17 & 0.77 & School, reg instab & \\
\hline \multicolumn{7}{|l|}{ Radio diffusion (radio) } \\
\hline High-bound & 0.0008 & 0.0007 & 1.28 & 0.81 & School, Prot80, Maj & \multirow{3}{*}{223 / 299} \\
\hline Base & -0.001 & 0.0007 & -2.16 & 0.67 & & \\
\hline Low-bound & -0.002 & 0.0007 & -2.82 & 0.72 & Mining, federal, polright & \\
\hline \multicolumn{7}{|l|}{ Newspaper readership (newsp) } \\
\hline High-bound & 0.0009 & 0.002 & 0.49 & 0.83 & Prot80, Federal, Instab & \multirow{3}{*}{$136 / 299$} \\
\hline Base & -0.005 & 0.002 & -2.29 & 0.67 & & \\
\hline Low-bound & -0.005 & 0.002 & -2.39 & 0.69 & Polright, mining & \\
\hline \multicolumn{7}{|l|}{ Television diffusion (tv) } \\
\hline High-bound & 0.0006 & 0.001 & 0.45 & 0.82 & School, Prot80, Instab & \multirow{3}{*}{$241 / 299$} \\
\hline Base & -0.003 & 0.002 & -1.43 & 0.65 & & \\
\hline Low-bound & -0.006 & 0.002 & -2.94 & 0.73 & Polright, mining, trade & \\
\hline \multicolumn{7}{|l|}{ Media ( $1^{\text {st }}$ component) } \\
\hline High-bound & 0.13 & 0.24 & 0.55 & 0.82 & Prot80, school, Instab & \multirow{3}{*}{$106 / 299$} \\
\hline Base & -0.66 & 0.22 & -2.98 & 0.69 & & \\
\hline Low-bound & -1.09 & 0.24 & -4.43 & 0.77 & Polright, Mining, Trade & \\
\hline \multicolumn{7}{|l|}{ Federalism (federal) } \\
\hline High-bound & 1.29 & 0.51 & 2.51 & 0.72 & Mining, Freeinfo, Polright & \multirow{3}{*}{96 / 299} \\
\hline Base & 0.99 & 0.52 & 1.89 & 0.66 & & \\
\hline Low-bound & 0.59 & 0.55 & 1.07 & 0.70 & Reg, Trade, Polright & \\
\hline \multicolumn{7}{|l|}{$\%$ vote on list (plist) } \\
\hline High-bound & 1.04 & 0.44 & 2.33 & 0.70 & Federal, Polright & \multirow{3}{*}{$225 / 299$} \\
\hline Base & 0.79 & 0.44 & 1.81 & 0.66 & & \\
\hline Low-bound & -0.44 & 0.44 & 1.01 & 0.81 & Legor_uk, Polright, Instab & \\
\hline \multicolumn{7}{|l|}{ District magnitude (dismag) } \\
\hline High-bound & 1.13 & 0.54 & 2.10 & 0.69 & Federal, Polright & \multirow{3}{*}{283 / 299} \\
\hline Base & 0.82 & 0.54 & 1.52 & 0.65 & & \\
\hline Low-bound & -0.98 & 0.54 & -1.81 & 0.82 & Trade, Legor_uk, Instab & \\
\hline \multicolumn{7}{|l|}{ Majoritarian rule (maj) } \\
\hline High-bound & 0.12 & 0.49 & 0.24 & 0.81 & Legor_uk,Polright,Instab & \\
\hline Base & -1.16 & 0.41 & -2.83 & 0.69 & & $130 / 299$ \\
\hline Low-bound & -1.35 & 0.41 & -3.30 & 0.72 & Federal, Polright & \\
\hline Political instability (instab) & & & & & & \\
\hline High-bound & -0.88 & 0.32 & -2.74 & 0.83 & Trade, Prot80, Freeinfo & \\
\hline Base & -1.55 & 0.31 & -5.06 & 0.76 & & 0 / 232 \\
\hline Low-bound & -1.77 & 0.37 & -4.83 & 0.78 & Trade, Federal, Polright & \\
\hline
\end{tabular}

Table 7b. EBA results for interactive terms

Dependent Variable: Corruption measured by the CPI97-99 index 


\begin{tabular}{|c|c|c|c|c|c|c|}
\hline Variable of Interest (M) & $\beta$ & $\begin{array}{c}\text { St. } \\
\text { Error }\end{array}$ & T-Stat & $\mathbf{R}^{2}$ & Z-Variables & N. Insignificant \\
\hline \multicolumn{7}{|l|}{ Democracy*maj } \\
\hline High-bound & 1.85 & 0.81 & 2.30 & 0.78 & Reg, Minino, Freeinfo & \\
\hline Base & 0.57 & 0.85 & 0.67 & 0.69 & & 232 / 232 \\
\hline Low-bound & -1.03 & 0.75 & -1.39 & 0.82 & Col_uk, Mining, Instab & \\
\hline \multicolumn{7}{|l|}{ Democracy*plist } \\
\hline High-bound & 0.60 & 0.83 & 0.72 & 0.79 & Trade, Avelf, Instab & \\
\hline Base & -0.82 & 0.93 & -0.88 & 0.67 & & $219 / 232$ \\
\hline Low-bound & -2.18 & 0.85 & -2.58 & 0.77 & Mining, School, Freeinfo & \\
\hline \multicolumn{7}{|l|}{ Democracy*dismag } \\
\hline High-bound & 1.06 & 0.90 & 1.17 & 0.82 & Col_uk, Avelf Instab & \\
\hline Base & -0.66 & 1.16 & -0.57 & 0.66 & & 232 / 232 \\
\hline Low-bound & -2.22 & 1.09 & -2.04 & 0.75 & Reg, Mining, Freeinfo & \\
\hline \multicolumn{7}{|l|}{ Democracy*freeinfo } \\
\hline High-bound & 0.07 & 0.03 & 2.23 & 0.72 & Federal & \\
\hline Base & 0.07 & 0.03 & 2.05 & 0.69 & & $205 / 232$ \\
\hline Low-bound & 0.008 & 0.03 & 0.27 & 0.81 & Reg, Maj, Instab & \\
\hline \multicolumn{7}{|l|}{ Democracy*media } \\
\hline High-bound & -0.03 & 0.67 & -0.05 & 0.73 & School, Avelf & \\
\hline Base & -0.26 & 0.67 & -0.39 & 0.71 & & 232 / 232 \\
\hline Low-bound & -1.43 & 0.65 & -2.19 & 0.78 & Reg, Trade & \\
\hline
\end{tabular}

Note:

The base $\beta$ is the estimated coefficient from the base regression consisting, in this case, of the interactive term of interest (M), lyp (I-Variables) and the variables in the interactive term taken as single factors. The High - Bound $\beta$ is the estimated coefficient of $\mathrm{M}$ corresponding to the regression that leads to the extreme high bound. The Low-Bound $\beta$ is the estimated coefficient of $\mathrm{M}$ corresponding to the regression that leads to the extreme low bound. The Z-Variables displayed in the sixth column are the control variables included in the regressions that produce the extreme bounds. N. Insignificant indicates the number of regressions which present the estimated coefficient $\beta$ statistically insignificant at the .05 confidence level. 